\title{
Strategi Ekonomi Islam Untuk Kesejahteraan Umat
}

\author{
Didi Suardi ${ }^{1}$, \\ ${ }^{1}$ Sekolah Tinggi Ekonomi Syariah Islamic Village Tangera, Banten \\ e-mail: didisuardi1104@gmail.com
}

\begin{abstract}
ABSTRAK. Kesejahteraan menurut sebagian masyarakat selalu dikaitkan dengan konsep kualitas hidup. Konsep kualitas hidup merupakan gambaran tentang keadaan kehidupan yang baik. Kesejahteraan pun menjadi bagian penting bagi suatu negara, bahkan, didirikannya atau dibentuknya sebuah negara salah satu tujuannya adalah dalam rangka mewujudkan kesejahteraan bagi seluruh masyarakatnya. Berbagai cara, metode, aturan, alat, pendekatan, ataupun kebijakan telah dipilih, ditempuh dan dilakukan oleh sebuah negara dalam rangka untuk mencapai tujuan tersebut. Definisi kesejahteraan dalam konsep masyarakat modern adalah sebuah kondisi dimana seorang dapat memenuhi segala kebutuhan, seperti makanan, minuman, pakaian, tempat tinggal, jaminan sosial, jaminan kesehatan, pendidikan, pekerjaan dan lainnya sebagai yang merupakan bagian dari kebutuhan, jika hilang komponen-komponen diatas maka eksistensi kehidupannya akan terancam. Kesejahteraan dalam ekonomi syariah bertujuan mencapai kesejahteraan manusia secara menyeluruh, yaitu kesejahteraan material, kesejahteraan spiritual dan moral. Konsep ekonomi kesejahteraan syariah bukan saja berdasarkan manifestasi nilai ekonomi, tetapi juga nilai spiritual dan moral. Konsepsi kesejahteraan dan kebahagiaan (falah) mengacu pada tujuan syariat Islam dengan terjaganya 5 prinsip dalam maqashid syari'ah, yakni terjanganya agama (ad-ddin), terjanganya jiwa (an-nafs), terjanganya akal (al-aql), terjanganya keturunan (an-nasl) dan terjanganya harta (al-mal). Kerjasamaan dan keadilan..
\end{abstract}

Kata kunci: Strategi, Ekonomi Islam, Kesejahteraan Umat.

\section{PENDAHULUAN}

Secara alamiah peta kehidupan manusia tidak bisa terlepaskan dari ekonomi untuk memenuhi kebutuhan hidupnya. Kebutuhan hidup manusia meliputi sandang, pangan dan papan. Awalnya kegiatan ekonomi masih sangat sederhana yakni melalui tukar-menukar barang atau disebut dengan barter dari satu orang ke orang lainnya, dari satu tempat ke tempat lainnya, dari satu daerah ke daerah lainnya, dengan prinsip satu sama lain saling membutuhkan dan tidak ada yang merasa dirugikan.

Ekonomi merupakan bagian yang tidak bisa terpisahkan dari kehidupan manusia dalam mengaktualisasikan dirinya untuk mencapai tujuan hidupnya. Islam sejalan dengan fitrah manusia yang bersifat holistik (syumul). Sejalan dengan perkembangan zaman dengan banyaknya kebutuhan manusia yang harus terpenuhi, maka dibutukan pula sebuah sistem ekonomi yang dapat mensejahterakan semua lapisan masyarakat. ${ }^{2}$ dimana muncul suatu pandangan yang menempatkan aspek material yang bebas dari dimensi moral. Pandangan

${ }^{1}$ Muhammad Wildan, Sistem Ekonomi Islam Simbol Kesejahteraan Masyarakat, El-Jizya; Islamic Economics Journal, Vol. 6, No. 1 Januari-Juni 2018, h. 49.

${ }^{2}$ Mustafa Nasution, Pengenalan Ekslusif Ekonomi Islam, (Jakarta: Kencana, 2007), h. 2. 
ekonomi materialisme ini yang kemudian mendorong perilaku manusia menjadi pelaku ekonomi yang hedonistik, sekularistik, dan materialistik. ${ }^{3}$

Berlangsungnya ekonomi pembangunan dunia ditandai dengan adanya kemajuan sains dan teknologi yang penuh dengan kompetisi. ${ }^{4}$ Sistem ini menjadi semakin popoler dan mendewakan kebebasan sebagai tulang punggung pembangunan ekonomi. Namun, dalam perjalanannya sistem kapitalisme ini gagal menciptakan pemerataan dan keadilam pembangunan, sehingga menyisahkan jarak ketimpangan yang semakin luas antar individu, kelompok dan wilayah dalam sector perekonomian, bahkan antar negara khusunya negara maju dan negara sedang berkembang.

Sementara itu Negara Sedang Berkembang mengalami kesulitan untuk membebaskan diri dari ketidakberdayaan, yang berimplikasi terhadap kemiskinan, pengangguran dan ekploitasi sumber daya alam yang semakin menghawatirkan. ${ }^{5}$ Berdasarkan penelitian dari 57 negara di dunia, pengukuran tersebut dilakukan menggunakan data Tingkat Kenaikan Pendapatan per Kapita Dunia dan Indeks Tingkat Konsumsi per Kapita dari tahun1950-1999 menunjukkan bahwa telah terjadi ketimpangan sangat signifikan. ${ }^{6}$

Dampak yang ditimbul dari cara pandang inilah yang kemudian membawa permasalahan baru dalam kehidupan sosial masyarakat seperti eksploitasi dan perusakan lingkungan hidup, disparitas (kesenjangan) pendapatan dan penumpukan kekayaan oleh segelintir orang, hilangnya sikap kebersamaan dan persaudaraan, munculnya penyakit persaingan yang tidak sehat dan lain sebagainya. Mencermati hal ini bahwa sistem ekonomi kapitalis telah gagal menyelesaikan persoalan kemanusiaan, keadilan ekonomi, pemerataan pendapatan dan kesenjangan sosial ekonomi.

Indoensia sebagai negara berpenduduk muslim terbesar di dunia masih kerap dikaitkan dengan persoalan kemiskinan dan pengangguran. Di tingkat internasional, Indonesia berada di peringkat yang jauh lebih rendah dibanding negara tetangga. Hasil studi IMD (International Institute for Management Delevopment) Swiss menempatkan Indonesia berada di nomor 45 dari 47 negara di dunia sebelum krisis 1998. Menurut Sutrisno Iwantono menyatakan bahwa kondisi perekonomian Indonesia secara makro masih menunjukkan performa yang baik, namun di sisi lain ketimpangan dan kemiskinan masih menyelimuti sebagian besar rakyat Indonesia. ${ }^{7}$ Permasalahan ekonomi yang dihadapi oleh bangsa Indonesia saat ini dinilai semakin menjauh dari tingkat kesejahteraan, hal ini bisa dilihat dari faktor pemicu terjadinya kesenjangan, ketimpangan dan pengangguran di masyarakat. Oleh karena itu, perlu adanya

${ }^{3}$ Hedonisme adalah pandangan hidup yang menganggap bahwa orang akan menjadi bahagia dengan mencari kebahagiaan sebanyak mungkin dan sedapat mungkin menghindari perasaan-perasaan yang menyakitkan; Sekularisme adalah sebuah ideologi yang menyatakan bahwa sebuah institusi atau badan negara harus berdiri terpisah dari agama atau kepercayaan; Materialisme adalah pandangan yang berisi orientasi, sikap, keyakinan, dan nilai-nilai hidup yang menekankan atau mementingkan kepemilikan barangbarang material atau kekayaan material di atas nilai-nilai hidup lainnya

${ }^{4}$ Hasan Aedy, Teori dan Aplikasi Pembangunan Perspektif Islam, (Yogyakarta: Graha Ilmu, 2011), h. 1.

${ }^{5}$ M. Umar Chapra, Islam dan Pembangunan Ekonomi, (Jakarta: Gema Insani, 2000), h. 64.

${ }^{6}$ Agus Maddison, Monitoring The World Economy, Oecd Paris dalam Sadono Sukirno, h. 40, Lihat Juga: Beckarman, International Comparition of Real Income, Development Centre of Thr Oecd dalam Sadono Sukirno, h. 72.

7 Qurratul A'yun Nailufarh, "Kesejahteraan Ekonomi Rakyat; diantara Harapan dan Realitas", Balance Economics, Bussiness, Management and Accounting Journal Th. VII No. 12 Januari 2010. 
pemecahan masalah dan kerjasama semua pihak, baik dari peran masyarakat maupun dari kebijakan pemerintah untuk mendorong perekonomian masyarakat.

Secara khusus, masalah pokok ekonomi rakyat seperti kemiskinan dan pengangguran kemungkinan besar akan tetap bertahan, karena masih banyaknya kepentingan birokrasi dan intervensi penguasa dan/atau kolomerat. Situasi ini akan terus memburuk, jika pemerintah terus memaksakan agenda-agenda ekonomi neo-liberal yang mengsampingkan kepentingan rakyat. Di luar intervensi modal internasional, ekonomi Indonesia pun sudah terlanjur terperangkap pada masalah-masalah struktural yang cukup berat, seperti aksi korupsi yang sudah menggurita sehingga menguras volume APBN, pembayaran angsuran pokok dan bunga utang luar negeri yang hampir menguras sepertiga APBN, kenaikan harga minyak bumi dunia yang berakibat pada terjadinya pembengkakan subsidi BBM dan derasnya kepentingan arus impor yang menyebabkan semakin terpinggirkannya pelaku ekonomi lokal.

Jika ini terus berlanjut, upaya peningkatan kesejahteraan rakyat mustahil dapat dilakukan, program-program pemerintah yang bersifat karitatif dan parsial $^{8}$, dalam jangka pendek program-program instan ini mungkin menolong. Akan tetapi untuk jangka panjang tidak cukup, perlu adanya estapet program-program permanen yang berjangka, terperogram dan terus berkesinambungan. Belum lagi, tingkat kemiskinan yang relative masih cukup tinggi, hal ini menjadi tantangan pemerintah untuk mengubah kekuatan masyarakat menjadi sumber daya yang produktif terutama dalam memenuhi pasokan kebutuhan dalam Negeri, tidak serta merta hanya tergantung pada produk impor. Hadiranya barang-barang impor yang murah dalam jumlah yang sangat besar, membuat pelaku ekonomi kecil dan menengah di Indonesia semakin sulit bangikit dan bersaing dengan produk-produk luar negeri. Jika tidak ada keterpihakan dan kebiajakan pemerintah untuk mendorong laju pertumbuhkan ekonomi berbasis local, tentu lambat hatun Indoensia akan terperangkap pada wilayah kecanduan dan ketergantungan terhadap pasokan barang-barang impor.

Terdapat beberapa penjelasan mengapa Indonesia masih belum bisa menciptakan perekonomian dengan tingkat kesejahteraan yang lebih baik. Dalam konteks dunia Internasional, Indonesia tidak bisa dikatakan sebagai failed-state, tidak juga sebagai negara yang belenggu hutang yang mematikan, namun harus diakui dan diwaspadai bahwa Indonesia sebenarnya dekat dengan situasi itu. Di tengah terpuruknya perekonomian dunia yang terus merosot dan melahirkan kemiskinan global, semakin menunjukkan bahwa sistem perekonomian yang selama ini dianut tidak mampu memberikan solusi kesejahteraan dan keadilan. Dalam kenyatannya salah satu akar masalah kemiskinan di berbagai negara akibat terjerat oleh utang yang tinggi. Pada saat yang bersamaan, perkembangan sistem ekonomi syariah justru semakin kokoh dan semakin teruji dalam menghadapi krisis ekonomi global.

Penjelasan ini, seakan memberi petunjuk bahwa sistem ekonomi syariah dinilai mempunyai peran penting dalam program pengentasan kemiskinan, karena prinsip yang dibangun oleh sistem ekonomi syariah ini lebih berorientasi pada kesejahteraan, kemanusiaan, persaudaraan, keadilan, kesucian, kehormatan, kedamaian, ketenangan, keruhaniaan dan keharmonisan yang dirasakan secara bersama, bukan hanya pengumpulan harta sebanyakbanyak sebagaimana yang dianut pada prinsip ekonomi konvensional.

\footnotetext{
${ }^{8}$ Karitatif yaitu bersifat memberi kasih sayang; parsial yaitu berhubungan atau merupakan bagian dari keseluruhan. https://kbbi.web.id
} 
Dalam sistem ekonomi syariah mengenal istilah bagi hasil, yang mana konsep ini memungkinkan beban kerugian dan keuntungan menjadi milik bersama dan ditanggung bersama antara pemilik modal dan pengelola. ${ }^{9}$ Penanggungan secara bersama ini berdampak positif bagi stabilitas perekonomian. Sistem ekonomi berbasis syariah juga memberlakukan adanya pelarangan terhadap praktek riba dan mendorong pada kegiatan sektor riil. Pelarangan riba dalam sistem ekonomi syariah ini pun terbukti mampu mengendalikan inflasi dan menjaga stabilitas perekonomian yang berdampak pada pertumbuhan ekonomi secara merata dan berkesinambungan.

Islam mengatur sedemikian rupa akan masalah ekonomi umatnya, khususnya dalam hal kemiskinan. Banyak faktor yang menjadi penyebab kemiskinan, di antaranya karena ketidakpedulian orang-orang kaya yang mana menyebabkan orang-orang miskin semakin terjerat pada lingkaran kemiskinannya. Merespon tentang kondisi tersebut, Islam memberlakukan kewajiban kepada umatnya untuk membayar zakat sesuai ketentuan yang berlaku, dan anjuran berinfak dan bershadaqah sesuai kemampuannya.

Dalam ajaran Islam terdapat dua prinsip utama dalam kegiatan ekonomi yakni, Pertama: Islam melarang satu pihak mengeksploitasi pihak lain dengan alasan apa pun, Kedua: Islam melarang satu pihak membedakan, membatasi, dan memisahkan dengan pihak lainnya. Islam memandang bahwa umat manusia bagaikan satu keluarga, oleh sebab itu, setiap manusia memiliki hak, kewajiban dan derajat yang sama dalam lingkup sosial ekonomi, yang membedakan hanyalah tingkat keimanan dan ketwaaanya kepada Allah SW'T. Begitu pun dalam pandangan hukum, setiap masyarakat ekonomi memiliki hak dan perlakuan yang sama dalam setiap kegiatan ekonomi, selama hak itu tidak bertentangan dengan norma-norma hukum yang ada.

Terciptanya kesejahteraan ekonomi rakyat merupakan tujuan utama berdirinya negara Republik Indonesia. Kesejahteraan dalam sistem ekonomi kapitalis hanya mengedepankan kebutuhan materi yang bersifat lahiriah, Konsep kesejahteraan menurut Islam lebih dari itu. Tulisan ini berangkat dari fenomena kegagalan sistem ekonomi kapitalis, dan memberikan alternatif sistem ekonomi Islam sebagai pemecahan masalah dari ketimpangan dan ketidakmerataan distribusi kekayaan yang menyebabkan radius kemiskinan semakin meningkat dan meluas.

\section{Sistem Ekonomi dalam Masyarakat}

Munculnya kegiatan ekonomi dalam masyarakat disebabkan oleh adanya kebutuhan dan keinginan manusia. Perbedaan ini tidak terlepas dari pengaruh filsafat, agama, ideologi dan kepentingan politik. Paul A. Samuelson (1970), sebagaimana dikutip Monzer Kahf mendefinisikan ilmu ekonomi sebagai kajian tentang perilaku manusia dalam hubungannya dengan pemanfaatan sumber-sumber produktif yang langka untuk memproduksi barangbarang dan jasa-jasa serta mendistribusikannya untuk kepentingan dikonsumsi. ${ }^{10}$ Dengan demikian, ilmu ekonomi merupakan suatu cara manusia untuk mencapai kesejahteraannya. Kesejahteraan yang dimaksud adalah segala sesuatu yang memiliki nilai dan harga.

9 Nihayatul Maskuro, "Gagasan Pemikiran Ekonomi Islam: Implementasi dan Usaha Pengembangannya", Li-Falah: Jurnal Studi Ekonomi dan Bisnis Islam Volume 2, Nomor 2, Desember 2017, h. 132.

10 Monzer Kahf, Ekonomi Islam: Telaah Analitik Terhadap Fungsi Sistem Ekonomi Islam, Terj. Machnun Husein, (Yogyakarta: Pustaka Pelajar, 1995), h. 2. 
Ada tiga sistem ekonomi yang kini cukup dominan di dunia saat ini, yaitu kapitalisme, sosialisme dan Islam. ${ }^{11}$ Berikut sistem ekonomi yang banyak digunakan di beberapa negara:

\section{Sistem Kapitalisme}

Paham kapitalisme berasal dari Inggris abad ke-18, kemudian menyebar ke Eropa Barat dan Amerika Utara. Sebagai akibat dari perlawanan terhadap ajaran gereja, tumbuh aliran pemikiran liberalisme di negara-negara Eropa Barat. Aliran ini kemudian merambah ke segala bidang termasuk bidang ekonomi. Dasar filosofis pemikiran ekonomi kapitalis bersumber dari tulisan Adam Smith ${ }^{12}$ dalam bukunya, An Inquiry into the Nature and Causes of the Wealth of Nations yang ditulis sekitar tahun 1776. Isi dari buku tersebut sarat dengan pemikiran-pemikiran tingkah laku ekonomi masyarakat.

Dari dasar filosofi tersebut kemudian menjadi sistem ekonomi dan pada akhirnya mengakar menjadi ideologi yang mencerminkan suatu gaya hidup (way of life). Smith berpendapat bahwa motif manusia melakukan kegiatan ekonomi adalah atas dasar dorongan kepentingan pribadi, bertindak sebagai tenaga pendorong yang membimbing manusia mengerjakan apa saja asal masyarakat sedia membayar. Motif dan prinsip sistem kapitalis adalah perolehan, persaingan dan rasionalitas. Sedangkan tujuan kegiatan ekonominya adalah perolehan menurut ukuran uang. ${ }^{13}$

\section{Sistem Sosialisme}

Sosialisme sebagaimana dirumuskan dalam Encyclopedia Britannica adalah suatu kebijakan atau teori yang bertujuan untuk memperoleh suatu distribusi yang lebih baik dengan tindakan otoritas demokrasi pusat. Prinsip-prinsip penting dalam sosialisme yang disosialisasikan kepada masyarakat, yaitu : Pertama, penghapusan milik pribadi atas alat-alat produksi. Hal ini akan digantikan menjadi milik pemerintah serta pengawasan atas industri dan pelayanan utama. Kedua; luasnya industri dan produksi mejadi kebutuhan sosial dan bukan kepada motif laba. Ketiga; pelayanan dan motif laba digantikan oleh motif pelayanan sosial.

Sosialisme muncul sebagai gerakan perlawanan ekonomi terhadap ketidakadilan yang timbul dari sistem kapitalisme. John Stuart Mill menyatakan gerakan sosialisme ditujukan untuk menolong orang-orang yang tidak beruntung dan tertindas. ${ }^{14}$

\section{Sistem Ekonomi Islam}

Muhammad Abdul Mannan mendefinisikan ekonomi Islam sebagai ilmu pengetahuan sosial yang mempelajari masalah-masalah ekonomi rakyat yang diilhami oleh

${ }^{11}$ M. Umer Chapra, Islam dan Tantangan Ekonomi, Terj. Nur Hadi Ihsan dan Rifqi Amar, Cet. I, (Surabaya: Risalah Gusti, 1999), h. 7.

12 John Adam Smith (5 Juni 1723-17 Juli 1790), adalah seorang filsuf berkebangsaan skotlandia yang menjadi pelopor ilmu ekonomi modern. Karyanya yang terkenal adalah buku an inquiry into the nature and causes of the wealth of nations (disingkat wealth of nations) adalah buku pertama yang menggambarkan sejarah perkembangan industri dan perdagangan di eropa serta dasar-dasar perkembangan perdagangan bebas dan kapitalisme. Adam smith adalah salah satu pelopor sistem ekonomi kapitalisme. Sistem ekonomi ini muncul pada abad 18 di eropa barat dan pada abad 19 mulai terkenal disana.

${ }^{13}$ Muhammad Abdul Manan, Ekonomi Islam: Teori dan Praktik, Terj. Potan Arif Harahap (Jakarta: Pt. Intermasa, 1992), h. 311.

${ }^{14}$ Hanifullah, "Membangun Sistem Ekonomi Umat Berbasis Syariah”, Jurnal Epistemé, Vol. 7, No. 2, Desember 2012, h. 271-279. 
nilai-nilai Islam. Ekonomi Islam merupakan sebuah konsep ekonomi yang dijalankan berdasarkan nilai-nilai dan prinsip-prinsip ajaran Islam yang bersumber pada al-Qur'an dan al-Sunnah, yang berorientasi pada pencapaian ridla Allah. Dalam hal ini, pencapaian ridla Allah adalah sebagai titik berangkat dari lahirnya ekonomi Islam.

Sistem ekonomi Islam yang dibangun berdasarkan nilai-nilai ajaran Islam yang tidak hanya berorientasi pada pencapaian profit semata, melainkan berorientasi pada nilai-nilai kemaslahatan bersama. Perbedaan mendasar antara ekonomi kapitalis dan ekonomi Islam, Dimana ekonomi konvensional berpijak pada dasar materialisme dan sekulerisme yang didasarkan hanya pada rasionalitas pemikiran manusia. Sedangkan ekonomi Islam pijakan dasarnya adalah al-Quran, as-Sunnah dan hasil ijtihad para intelektual muslim.

\section{Makna Kesejahteraan Ekonomi}

Kesejahteraan menurut sebagian masyarakat selalu dikaitkan dengan konsep kualitas hidup. Konsep kualitas hidup merupakan gambaran tentang keadaan kehidupan yang baik. Undang-undang Nomor 13 tahun 1998 menjelaskan tentang arti dari kesejahteraan. Kesejahteraan didefinisikan sebagai suatu tata kehidupan dan penghidupan sosial baik material maupun spiritual yang diliputi rasa keselamatan, kesusilaan, dan ketentraman lahir batin.

Kesejahteraan juga menjadi bagian penting bagi suatu negara, bahkan, didirikannya atau dibentuknya sebuah negara salah satu tujuannya adalah dalam rangka mewujudkan kesejahteraan bagi seluruh masyarakatnya. Berbagai cara, metode, aturan, alat, pendekatan, ataupun kebijakan telah dipilih, ditempuh dan dilakukan oleh sebuah negara dalam rangka untuk mencapai tujuan tersebut. Oleh sebab itu, seorang Kepala Negara harus focus bagaimana menserjahterakan masyarakatnya, berikut konsep kesejahteraan ekonomi dalam ekonomi konvensipnal dan ekonomi islam:

\section{Makna Kesejahteraan dalam Ekonomi Konvensional}

Definisi kesejahteraan dalam konsep masyarakat modern adalah sebuah kondisi dimana seorang dapat memenuhi segala kebutuhan, seperti makanan, minuman, pakaian, tempat tinggal, jaminan sosial, jaminan kesehatan, pendidikan, pekerjaan dan lainnya sebagai yang merupakan bagian dari kebutuhan, jika hilang komponen-komponen diatas maka eksistensi kehidupannya akan terancam. ${ }^{15}$

Konsep ekonomi konvensional dibangun dengan pengaruh bayangan kekokohan hukum fisika Newton, sebagaimana yang dikatakan oleh Jean Baptiste Say, bahwa sama halnya dengan jagat raya, ekonomi akan berjalan dengan baik jika ia dibiarkan berjalan sendiri. Produksi akan menciptakan permintaannya sendiri, dimana setiap kelebihan produksi atau pengangguran akan dapat dikoreksi secara otomatis.

Kekuatan-kekuatan pasar akan menciptakan 'tatanan' dan 'keharmonisan. Setiap upaya dari pihak pemerintah untuk melakukan intervensi sebagai penyesuaian hanya akan menimbulkan distorsi dan in-efisiensi. Adam Smith menyatakan bahwa terdapat simetri antara kepentingan publik dan swasta. Jika setiap orang dibiarkan melampiaskan kepentingannya sendiri, maka secara lamgsung akan mendorong kepentingan masyarakat lain sehingga menciptakan suatu keharmonisan antara kepentingan privat dan publik.

15 Warkum Sumito, Asas-asas Perbankan Islam dan Lembaga-lembaga Terkait. Cet. Ke-4, (Jakarta: Raja Grafindo Persada, 2010), h. 17, Lihat Juga: Ikhwan Abidin Basri, Islam dan Pembangunan Ekonomi. (Jakarta: Gema Insani Press 2005), h. 24. Lihat juga: Dominick Salvatone, Teori Mikroekonomi, (Jakarta: Erlangga, 2009), h. 56. 
Persaingan bebas antar individu dalam suatu pasar atau wilayah akan menjamin terwujudnya kesejahteraan umum. Sistem pasar diyakini akan mengantarkan kepada penggunaan sumber daya yang efisien ketika para pengusaha swasta dibiarkan kebebasan merealisasikan tujuan ekonominya

\section{Makna Kesejahteraan dalam Ekonomi Islam}

Kesejahteraan ekonomi syariah bertujuan mencapai kesejahteraan manusia secara menyeluruh, yaitu kesejahteraan material, kesejahteraan spiritual dan moral. Konsep ekonomi kesejahteraan syariah bukan saja berdasarkan manifestasi nilai ekonomi, tetapi juga nilai spiritual dan moral. ${ }^{16}$ Konsepsi kesejahteraan dan kebahagiaan (falah) mengacu pada tujuan syariat Islam dengan terjaganya 5 prinsip dalam maqashid syari'ah, yakni terjanganya agama (ad-ddin), terjanganya jiwa (an-nafs), terjanganya akal (al-aql), terjanganya keturunan (an-nasl) dan terjanganya harta (al-mal). Secara terperinci, tujuan ekonomi Islam dapat dijelaskan sebagai berikut:

a. Kesejahteraan ekonomi mencakup kesejahteraan individu, masyarakat dan negara.

b. Tercukupinya kebutuhan dasar manusia, meliputi makan, minum, pakaian, tempat tinggal, kesehatan, pendidikan, keamanan dan sistem negara yang menjamin terlaksananya kecukupan kebutuhan dasar secara adil. ${ }^{17}$

c. Penggunaan berdaya secara optimal, efisien, efektif, hemat dan tidak mubazir.

d. Distribusi harta, kekayaan, pendapatan dan hasil pembangunan secara adil dan merata.

e. Menjamin kebebasan individu.

f. Kesamaan hak dan peluang.

g. Kerjasamaan dan keadilan. ${ }^{18}$

Ekonomi Islam kini telah menjadi pembahasan tersendiri pada masa modern sekarang ini. Kajian-kajian telah banyak dilakukan oleh para ulama mengingat pada masa awal pertumbuhan Islam, ekonomi Islam belum muncul sebagai sebuah disiplin keilmuan. Meskipun demikian, pondasi atau landasan dasarnya telah terealisasi di dalam sejarah Islam, sehingga hal inilah yang merupakan warisan yang terus menjadi sumber bagi berkembangnya nilai-nilai ekonomi Islam. Para ulama berperan besar di dalam memberikan penjelasan kepada para pelaku ekonomi dalam menjalankan kegiatan muamalahnya.

Kesejahteraan menurut al-Ghazali adalah tercapainya kemaslahatan. Kemaslahatan sendiri merupakan terpeliharanya tujuan syara' (Maqasid al-Shari'ah). Manusia tidak dapat merasakan kebahagiaan dan kedamaian batin, melainkan setelah tercapainya kesejahteraan yang sebenarnya dari seluruh umat manusia di dunia melalui pemenuhan kebutuhankebutuhan ruhani dan materi. Untuk mencapai tujuan syara agar dapat terealisasinya

\footnotetext{
${ }^{16}$ M. B. Hendrie Anto, Pengantar Ekonomika Mikro Islami, (Yogyakarta: Ekonisia, 2003), h. 7.

${ }^{17}$ Warkum Sumito, Asas-asas Perbankan Islam \& Lembaga-lembaga Terkait. Cet Keempat, (Jakarta: Raja Grafindo Persada, 2010), h. 17.

${ }^{18}$ Umer Chapra, Islam dan Tantangan Ekonomi, (Jakarta : Gema Insani Press, 2000), h. 304. Lihat juga: A. Ghofar Purbayastrategi, "Peningkatan Kesejahteraan Ekonomi Masyarakat: Kasus Pengusaha Krupuk dan Camilan Hasil Laut di Pantai Kenjeran Lama Surabaya", Oeconomicus; Journal Of Economics Volume 1, No. 1, Des 2016, h. 75-79.
} 
kemaslahatan, beliau menjabarkan tentang sumber kesejahteraan, yakni: terpeliharanya agama, jiwa, akal, keturunan dan harta. ${ }^{19}$

Konsep kesejahteraan tersebut dalam pandangan ekonomi Islam masih mencakup hanya dimensi materi. Ekonomi Islam menghendaki kesejahteraan itu juga mencakup keseluruhan unsur materi dan non materi (psikis). Hal ini disebabkan kepuasan manusia itu terletak pada unsur-unsur non materi. Kesejahteraan dalam fungsi matematisnya dapat dilihat dibawah ini. ${ }^{20}$

$$
\mathbf{I W}=\mathrm{MQ}+\mathrm{SQ}
$$

\section{Keterangan: \\ IW = Islamic Welfare (Kesejahteraan yang Islami) \\ MQ = Material Quetient (Kecerdasan Material \\ $\mathrm{SQ}=$ Spiritual Quetient (Kecerdasan Spiritual)}

Dalam fungsi diatas dapat diketahui bahwa kesejahteraan yang optimal dapat tercapai apabila kecerdasan material dikontrol oleh kecerdasan spiritual mulai dari cara memperolehnya sampai kepada membelanjakan. Dalam prakteknya, mereka yang memiliki kecerdasan spiritual dapat menjadi tenteram, aman, dan sejahtera meskipun mereka tidak memiliki kecerdasan material. Sedangkan manusia yang hanya memiliki kecerdasan material tidak akan pernah mendapatkan kebahagiaan meskipun dengan harta yang melimpah.

Kecerdasan Islami merupakan bagian fungsi dari kecerdasan material dan kecerdasan spiritual. Kecerdasan Islami dapat dicapai apabila hal-hal sebagai berikut dilakukan, yakni: benda yang dimiliki diperoleh dengan cara halal dan baik, bertujuan untuk ibadah, kualitas lebih dipentingkan daripada kuantitas, dan penggunaannya sesuai syariah. ${ }^{21}$ Hal ini pun telah banyak dibahsas dalam al-Quran dan juga telah diaplikasikan dalam kehidupan Nabi Muhammad SAW.

\section{Kesejahteraan Menurut al-Qur'an}

Kesejahteraan merupakan tujuan dari ajaran Islam dalam bidang ekonomi. Kesejahteraan merupakan bagian dari rahmatan lil alamin yang diajarkan oleh Agama Islam ini. Namun kesejahteraan yang dimaksudkan dalam Al-Qur'an bukanlah tanpa syarat untuk mendapatkannya. Kesejahteraan akan diberikan oleh Allah SWT jika manusia melaksanakan apa yang diperintahkannya dan menjauhi apa yang dilarangnya. ${ }^{22}$

Banyak ayat Al-Qur'an yang memberikan penjelasan tentang kesejahteraan ada yang secara langsung (tersurat) dan ada yang secara tidak langsung (tersirat) berkaitan dengan permasalahan ekonomi. Namun demikian, penjelasan dengan menggunakan dua cara ini menjadi satu pandangan tentang kesejahteraan. Allah SWT. berfirman dalam surah Al-Nahl ayat 97 yang berbunyi:

${ }^{19}$ Abdur Rohman, Ekonomi al-Ghazali, Menelusuri Konsep Ekonomi Islam dalam Ihya' Ulum al-Din. (Surabaya: Bina Ilmu, 2010).

${ }^{20}$ Hasan Aedy, Teori dan Aplikasi Ekonomi Pembangunan Perspektif Islam Sebuah Studi Komparasi, (Yogyakarta: Graha Ilmu, 2011).

${ }^{21}$ Almizan, "Distribusi Pendapatan: Kesejahteraan Menurut Konsep Ekonomi Islam”, Maqdis; Jurnal Kajian Ekonomi Islam, Volume 1, No. 1, Januari-Juni 2016, h. 73-78.

${ }^{22}$ Darsyaf Ibnu Syamsuddien, Prototype Negeri Yang Damai, (Surabaya: Media Idaman Press, 1994). 


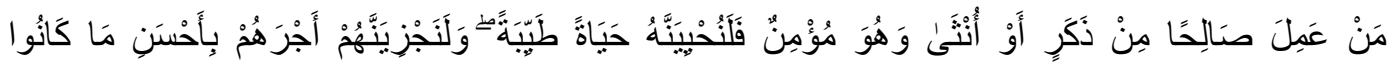
يَعْمَلُونَ Artinya: "Barangsiapa yang mengerjakan amal saleh, baik laki-laki maupun perempuan dalam keadaan beriman, maka sesunggubnya akan Kami berikan kepadanya kehidupan yang baik dan sesungguhnya akan Kami beri balasan kepada mereka dengan pabala yang lebib baik dari apa yang telah mereka kerjakan”. (QS. al-Nahl: 97)

\section{Kesejahteraan di Masa Rasulullah SAW.}

Ajaran Islam telah menjelaskan bahwa sesungguhnya tujuan dasar Islam adalah terwujudnya kesejahteraan baik di dunia maupun akhirat. Dalam prakteknya, Rasulullah SAW. Membangun suatu perekonomia yang dulunya dari titik nol menjadi suatu perekonomian raksasa yang mampu menembus keluar dari jazirah Arab. Pemerintahan yang dibangun Rasulullah SAW di Madinah mampu menciptakan suatu aktivitas perekonomian yang membawa kemakmuran dan keluasan pengaruh pada masa itu. ${ }^{23}$

Kegiatan ekonomi telah menjadi sarana pencapaian kesejahteraan atau kemakmuran. Nabi Muhammad SAW memperkenalkan sistem ekonomi Islam. Hal ini berawal dari kerja sama antara kaum Muhajirin dan Anshar. Sistem ekonomi Islam yang diperkenalkan, antara lain, syirkah, qirad, dan khiyar dalam perdagangan. Selain itu, juga diperkenalkan sistem musaqah, mukhabarah, dan muzara'ah dalam bidang pertanian dan perkebunan. Para sahabat juga melakukan perdagangan dengan penuh kejujuran. Mereka tidak mengurangi timbangan di dalam berdagang.

Semenjak hijrah ke Madinah, kehidupan telah banyak berubah. Para sahabat Nabi Muhammad SAW dari kaum Muhajirin bahu membahu dengan penduduk lokal Madinah dari kaum Anshar dalam membangun kegiatan ekonomi. Berbagai bidang digeluti oleh beliau dan para sahabatnya baik itu pertanian, perkebunan, perdagangan dan peternakan. Pasar-pasar dibangun di Madinah. Kebunkebun kurma menghasilkan panenan yang melimpah. Peternakan kambing menghasilkan susu yang siap dipasarkan maupun hanya sekedar untuk diminum. Dalam sejarah, dikenal tokoh Islam yang terkenal dengan kekayaannya dan kepiawaiannya dalam berdagang dan berbagai bidang lainnya. ${ }^{24}$

Mereka adalah Abdurahman bin Awf, Abu Bakr, 'Umar bin Khattab, dan sebagainya. Mereka sadar akan dapat hidup di Madinah hanya dengan usaha mereka sendiri. Masyarakat Madinah terus berupaya meningkatkan aktivitas ekonomi dengan etos kerja yang tinggi. Ibadah dan kerja adalah dua jenis aktivitas ukhrawi dan duniawi yang menghiasi hari-hari mereka silih berganti. Pada awal tahun kedua Hijrah, Allah SWT sudah mewajibkan kaum muslimin membayar zakat. Tentu saja, zakat yang diwajibkan hanya bagi mereka yang telah berkecukupan (Zainal Abidin Ahmad, 1974).

\section{Strategi Ekonomi Islam untuk Kesejahteraan Umat}

Para ekonom muslim banyak membicarakan objektivitas perekonomian berbasis Islam pada level negara pemenuhan kebutuhan dasar, negara wajib bekerja untuk meningkatkan kesejahteraan materi bagi lingkungan sosial maupun individu dengan memamfaatkan

${ }^{23}$ Muhammad Sholahuddin, World Revolution With Muhammad, (Sidoarjo: Mashun, 2009).

${ }^{24}$ Muhammad Husain Haekal, Sejarah Hidup Muhammad, (Jakarta: Litera Antar Nusa, 1989). 
sumber daya yang tersedia. Negara pun wajib mengeluarkan kebijakan yang mengupayakan akan stabilitas ekonomi, kesetaraan, ketenegakerjaan, pembangunan sosial ekonomi, dan lain sebagainya. agar dapat menciptakan kesejahteraan bagi masyarakat perlunya dulakukan strategi, diantaranya:

Kebijakan fiskal yang dilakukan nabi Muhammad saw pada abad ke-7 M, merupakan model baru dalam bidang keuangan negara. ${ }^{25}$ Instrumen kebijakan fiskal dimaksudkan untuk meningkatkan pendapatan negara dan tingkat partisipasi kerja (agregate demand), sehingga semua lahan pertanian di kota Madinah dimanfaatkan secara maksimun. Sektor pertanian difokuskan pada sistem mudarabah, muzara'ah, dan musaqah, sehingga tidak mengherankan jika penarikan pajak pertanian yang diserahkan kepada negara cukup signifikan. Selanjutnya, pada pemerinthan khalifah Umar bin Abdul Aziz mencatat prestasi yang memukau, hampir tidak ada yang mau menerima zakat, lantaran penduduknya telah sejahtera secara ekonomi. ${ }^{26}$

Tampak sejarah telah membuktikan bahwa sebuah negara akan menjadi makmur, bila pemerintah yang berkuasa beriman, bertakwa dan bermoral, serta seluruh pejabatnya menerapkan pola hidup sederhana. Dalam hal ini terdapat beberapa lima pilar utama untuk mencapai kesejahteraan dalam sebuah negara, diantaranya:

1. Para penguasa, pejabat dan rakyatnya tidak lagi serakah, menjunjung pola hidup sederhana, tidak boros, namun juga tidak kikir.

2. Pengelolaan sumber kekayaan alam oleh negara dipergunakan sebaik-baiknya untuk perbaikan taraf hidup masyarakat-nya.

3. Keadilan hukum harus ditegakan dengan seadil-adilnya, tanpa tebang pilih.

4. Menjujung tinggi kesadaran berzakat bagi masyarakat yang telah memenuhi ketentuan.

5. Mengelola lembaga Amil Zakat secara professional, transfaran, akutabel dan tepat sasaran.

Jika lima dasar utama di atas dijalankan dengan baik, maka akan berdampak besar kemaslahatan manusia.

\section{Prinsip Kepemilikan dalam Ekonomi Islam}

Islam sebagai agama rahmat bagi segenap manusia dan alam akan memperkuat pembangunan ekonominya dengan berbagai usaha dan penghasilan yang halal. Demikian pula dalam penanganan kemiskinan, pengangguran dan kesenjangan dilakukan dengan cara yang dibolehkan dalam syariat. Menurut Aedy, kepemilikan dalam perspektif ekonomi Islam terbagi menjadi tiga macam, yakni:

\section{Kepemilikan Individu}

Kepemilikan individu dihargai, dihormati dan diakui semua orang, sehingga siapapun akan merasa aman dan nyaman. Adapun dalam pemanfaatannya, melekat sebuah kewajiban yang mana tidak boleh merugikan orang lain dan selalu berorientasi niat beribadah kepada Allah. Zakat wajib dikeluarkan jika telah sampai mencapai haul dan nisab.

\section{Kepemilikan Umum}

${ }^{25}$ Kadim As-Sadr, "Fiscal Policiesin Aerly Islam”, h. 78-80. 2016. h. 8 .

${ }^{26}$ Djumadi, “Konsep Pembangunan Ekonomi Perspektif Islam”, Jurnal Tahkim Vol. XII, No. 1, Juni 
Jika Keyne menghendaki campur tangan pemerintah dalam perekonomian, maka dalam Islam campur tangan pemerintah hanyalah dalam bentuk pengendalian dan kebijakan, dan hasilnya sebesar-besarnya diserahkan kepada umat untuk mendorong peningkatan kesejahteraan ekonomi, sehingga pemeliharaan dan keseimbangan tetap terjaga.

\section{Kepemilikan Negara}

Sumber-sumber pendapatan negara untuk negara. Negara akan mengatur pemanfaatannya untuk keperluan keamanan, ketertiban, infrastruktur dan lainnya yang menyangkut akan hajat hidup rakyatnya.

\section{KESIMPULAN}

Kesejahteraan menurut sebagian masyarakat selalu dikaitkan dengan konsep kualitas hidup. Konsep kualitas hidup merupakan gambaran tentang keadaan kehidupan yang baik. Kesejahteraan pun menjadi bagian penting bagi suatu negara, bahkan, didirikannya atau dibentuknya sebuah negara salah satu tujuannya adalah dalam rangka mewujudkan kesejahteraan bagi seluruh masyarakatnya. Berbagai cara, metode, aturan, alat, pendekatan, ataupun kebijakan telah dipilih, ditempuh dan dilakukan oleh sebuah negara dalam rangka untuk mencapai tujuan tersebut.

Definisi kesejahteraan dalam konsep masyarakat modern adalah sebuah kondisi dimana seorang dapat memenuhi segala kebutuhan, seperti makanan, minuman, pakaian, tempat tinggal, jaminan sosial, jaminan kesehatan, pendidikan, pekerjaan dan lainnya sebagai yang merupakan bagian dari kebutuhan, jika hilang komponen-komponen diatas maka eksistensi kehidupannya akan terancam.

Kesejahteraan dalam ekonomi syariah bertujuan mencapai kesejahteraan manusia secara menyeluruh, yaitu kesejahteraan material, kesejahteraan spiritual dan moral. Konsep ekonomi kesejahteraan syariah bukan saja berdasarkan manifestasi nilai ekonomi, tetapi juga nilai spiritual dan moral. Konsepsi kesejahteraan dan kebahagiaan (fala $>$ b) mengacu pada tujuan syariat Islam dengan terjaganya 5 prinsip dalam maqashid syari'ah, yakni terjanganya agama (ad$d d i>n$ ), terjanganya jiwa (an-nafs), terjanganya akal (al-aql), terjanganya keturunan (an-nasl) dan terjanganya harta $(a l-m a>$ l). Secara terperinci, tujuan ekonomi Islam dapat dijelaskan sebagai berikut:

1. Kesejahteraan ekonomi mencakup kesejahteraan individu, masyarakat dan negara.

2. Tercukupinya kebutuhan dasar manusia, meliputi makan, minum, pakaian, tempat tinggal, kesehatan, pendidikan, keamanan dan sistem negara yang menjamin terlaksananya kecukupan kebutuhan dasar secara adil.

3. Penggunaan berdaya secara optimal, efisien, efektif, hemat dan tidak mubazir.

4. Distribusi harta, kekayaan, pendapatan dan hasil pembangunan secara adil dan merata.

5. Menjamin kebebasan individu.

6. Kesamaan hak dan peluang.

7. Kerjasamaan dan keadilan. 


\section{DAFTAR PUSTAKA}

Aedy, Hasan. Teori dan Aplikasi Ekonomi Pembangunan Perspektif Islam Sebuah Studi Komparasi. Yogyakarta: Graha Ilmu, 2011.

Anshari, Endang Saiffudin. Ilmu Filsafat dan Agama. Surabaya: PT. Bina Ilmu, 1981.

Anto, M.B. Hendrie. Pengantar Ekonomika Mikro Islami, Cet.I. Yogyakarta: Ekonosia, 2003.

Arsyad, Lincoln. Ekonomi Mikro. Jakarta: Gemapress, 1999.

As-Suyuthi, Imam Jalaluddin. al-Asybah Wan-Nadhoir. Surabaya: al-Haromain, Tth.

Basri, Ikhwan Abidin. Islam dan Pembangunan Ekonomi. Jakarta: Gema Insani Press 2005.

Beckarman, International Comparition of Real Income, Development Centre of Thr Oecd dalam Sadono Sukirno.

Chapra, M. Umar. Islam dan Pembangunan Ekonomi. Jakarta: Gema Insani, 2000. Islam dan Tantangan Ekonomi, Terj. Nur Hadi Ihsan dan Rifqi Amar, Cet. I. Surabaya: Risalah Gusti, 1999. . Masa Depan Ilmu Ekonomi Sebuah Tinjauan Islam, Cet. I. Jakarta: Gema Insani Press, 2001.

The Future of Economics: An Islamic Perspective. Terj. Jakarta: Sebi, 2001.

Djumadi. "Konsep Pembangunan Ekonomi Perspektif Islam”. Jurnal Tahkim Vol. XII, No. 1, Juni 2016.

Haekal, Muhammad Husain. Sejarah Hidup Muhammad. Jakarta: Litera Antar Nusa, 1989.

Hamid, M. Arfin. "Ekonomi Klasik ke Sistem Syariah", bttp:/ / mmw-fajar. co.id

Hanifullah, "Membangun Sistem Ekonomi Umat Berbasis Syariah", Jurnal Epistemé, Vol. 7, No. 2, Desember 2012.

Jogiyanto. Analisis dan Desain Sistem Informasi. Yogyakarta: Andi, 2005.

Kahf, Monzer. Ekonomi Islam: Telaah Analitik Terbadap Fungsi Sistem Ekonomi Islam, Terj. Machnun Husein. Yogyakarta: Pustaka Pelajar, 1995.

Karim, Adiwarman. Ekonomi Islam: Suatu Kajian Ekonomi Makro, Cet. I. Jakarta: IIIT Indonesia, 2002.

Karim, Adiwarman. Ekonomi Mikro Islami, Cet. II. Jakarta: IIIT Indonesia, 2003.

Maddison, Agus. Monitoring The World Economy, Oecd Paris dalam Sadono Sukirno.

Mannan, Muhammad Abdul. Ekonomi Islam: Teori dan Praktik, Terj. Potan Arif Harahap. Jakarta: PT. Intermasa, 1992.

. Teori dan Praktek Ekonomi Islam, Terj. Nastangin. Yogyakarta: PT. Dana Bhakti Wakaf, 1997.

Maskuro, Nihayatul. "Gagasan Pemikiran Ekonomi Islam: Implementasi dan Usaha Pengembangannya”, Li-Falah: Jurnal Studi Ekonomi dan Bisnis Islam Volume 2, Nomor 2, Desember 2017.

Nailufarh, Qurratul A'yun. "Kesejahteraan Ekonomi Rakyat; diantara Harapan dan Realitas", Balance Economics, Bussiness, Management and Accounting Journal Th. VII No. 12 Januari 2010.

Nasution, Mustafa. Pengenalan Ekslusif Ekonomi Islam. Jakarta: Kencana, 2007.

Purbaya, A. Ghofar. "Strategi Peningkatan Kesejahteraan Ekonomi Masyarakat: Kasus Pengusaha Krupuk dan Camilan Hasil Laut di Pantai Kenjeran Lama Surabaya”. Oeconomicus; Journal Of Economics Volume 1, No. 1, Des 2016. 
Rohman, Abdur. Ekonomi Al-Ghazali; Menelusuri Konsep Ekonomi Islam dalam Ihya' Ulum al-Din. Surabaya: Bina Ilmu, 2010.

Salvatone, Dominick. Teori Mikroekonomi. Jakarta : Erlangga, 2009.

Sholahuddin, Muhammad. World Revolution with Muhammad. Sidoarjo: Mashun, 2009.

Shomad, Abd. Hukum Islam. Jakarta: Kencana, 2010.

Suherman, Bonnie dan Marin Pinontoan. Designing Information System. Jakarta: Elex Media Komputindo, 2008.

Sumito, Warkum. Asas-asas Perbankan Islam \& Lembaga-lembaga Terkait. Cet Keempat. Jakarta: Raja Grafindo Persada, 2010.

Syamsuddien, Darsyaf Ibnu. Prototype Negeri Yyng Damai. Surabaya: Media Idaman Press, 1994.

Syarifuddin, Amir. Ushul Fiqh, Jilid 1. Jakarta: Kencana, 2011.

Wildan, Muhammad. "Sistem Ekonomi Islam Simbol Kesejahteraan Masyarakat". El-Jizya; Islamic Economics Journal, Vol. 6, No. 1 Januari-Juni 2018. 